\title{
Original article \\ Geographical discrimination of honeys through antioxidant capacity, mineral content and colour
}

\author{
Mariela Patrignani, ${ }^{1}$ Cecilia Bernardelli, ${ }^{2}$ Paula A. Conforti, ${ }^{1,3}$ Néstor H. Malacalza, ${ }^{4}$ Diego K. Yamul, ${ }^{1}$ \\ Edgardo Donati $^{2} \&$ Cecilia E. Lupano ${ }^{1} *$ \\ 1 Centro de Investigación y Desarrollo en Criotecnología de Alimentos (CIDCA), Facultad de Ciencias Exactas, UNLP - CCT La Plata - \\ CONICET, 47 y 116, 1900 La Plata, Argentina \\ 2 Centro de Investigación y Desarrollo en Fermentaciones Industriales (CINDEFI), Facultad de Ciencias Exactas, UNLP - CCT La Plata - \\ CONICET, 50 No 227, 1900 La Plata, Argentina \\ 3 Facultad de Ciencias Agrarias y Forestales, UNLP, 60 y 116, 1900 La Plata, Argentina \\ 4 Ministerio de Agricultura, Ganadería y Alimentación. Lab. de Calidad de Miel, 13 y 532 - 1900, La Plata, Argentina
}

(Received 8 April 2015; Accepted in revised form 30 June 2015)

Summary The assessment of geographical origin of honey is economically important for producers and consumers as every region may present particular quality characteristics. In this study, honeys from the seven different regions of Buenos Aires province (Argentina) were characterised by their antioxidant capacity (DPPH, FRAP), total phenolic content (TPC), mineral composition, colour and ash. Honeys showed significant differences among their antioxidant capacity (DPPH), ash, colour and mineral content $(P \leq 0.05)$. Besides, a good antioxidant activity and low amounts of $\mathrm{Cu}$ and $\mathrm{Zn}\left(<1.0-1.5\right.$ and $0.7-1.8 \mathrm{mg} \mathrm{kg}^{-1}$, respectively) were found in the samples. Significant Pearson's correlations $(P \leq 0.05)$ among the different parameters were found. Moreover, the linear discriminant analysis allowed the classification of honeys in their original groups with a prediction success of $98 \%$. The present results suggest that honeys could be correctly classified by their geographical origin through their TPC, colour, ash and mineral concentrations.

Keywords Antioxidants, classification, honey, linear discriminant analysis, minerals, principal component analysis.

\section{Introduction}

Honey is a worldwide known product naturally made by honeybees through the collection of nectar. It's sweet taste, light flavour and attractive colour make this foodstuff a generally well-accepted sugar substitute (Alves et al., 2013).

Moreover, it has been suggested that honey intake increases serum antioxidant potential and may present antitumour effects (Swellam et al., 2003; Kuś et al., 2014). The antioxidant activity of honey is the result of phenolic compounds, peptides, organic acids, enzymes, Maillard reaction products and, probably, other minor components (Socha et al., 2011).

Honey composition is strongly associated to its botanical origin and is closely related to the geographical area where honey is produced. The determination of both, botanical and geographical origin, is a fundamental issue in the market because every region may

*Correspondent: Fax: + 54-221-4254853;

e-mail: cel@quimica.unlp.edu.ar present particular quality standards that determine its commercial value (Baroni et al., 2009). Therefore, the assessment of honey origin is very important not only for consumers but also for producers. The mineral composition of honey reflects the mineral composition of the forage area of the hive (González Paramás et al., 2000). Hence, honey mineral content could provide valuable information in the geographical discrimination of samples.

The quality of Argentinean honeys is recognised worldwide: this country is the second largest exporter after China. Currently, the main export destinations of the Argentinean market are Unites States (67\%), Germany $(11 \%)$ and Japan (6\%) (Blengino, 2013). More than $50 \%$ of Argentine's honey production is accounted in the Buenos Aires province which can be divided into seven regions. Honeys from these regions have been characterised by its physicochemical parameters, oligosaccharide profiles and botanical origin (Arias et al., 2003; Malacalza et al., 2005, 2007), but the antioxidant capacity and mineral composition of the entire province remain unstudied. Moreover, it has 
been documented that these parameters could provide enough information for honey geographical discrimination (Pasquini et al., 2014). However, this model was only evaluated to discriminate among three different regions, and little work has been carried out in order to find a successful method to discriminate among a higher number of regions.

In this work, honeys from the seven regions of the Buenos Aires province were studied. The mineral composition, antioxidant activity, colour, total phenolic and ash contents were determined. The aims of this study were as follows: characterise honeys from the different Buenos Aires regions; determine possible relationships between the different parameters studied; suggest possible pollution indicators; and find parameters which best discriminate honeys from different regions. Thus, this work proposes a significant achievement in honey classification, as an important number of geographically close regions was analysed.

\section{Material and methods}

\section{Honey samples}

This study was carried out on samples of blossom honey, collected from the province of Buenos Aires. This province is divided into seven geographical regions: Paranaense region (I), Espinal region, districts of Talar (II) and Caldén (III); Pampeana region, districts Oriental (IV), Occidental (V) and Austral (VI); and Monte region (VII) (Fig. 1). The number of samples from the different regions used in the tests is shown in Table 1. Due to limitations in the use of equipments and the amount of sample, the determinations were performed in different number of samples, which were selected randomly. Also, some anomalous data were discarded using box plot (Pellerano et al., 2012).

To ensure that honey was not modified during the extraction procedure, all samples were obtained by cold extraction at the laboratory, by direct compression of the honeycombs, and then filtered through a fine sieve, to remove impurities. Samples were stored in the dark at $-20{ }^{\circ} \mathrm{C}$ until analysis.

The botanical origin of the monofloral honey samples is detailed in Fig. 1. The rest of the samples were multifloral honey.

\section{Mineral content}

Honey samples were accurately weighed $(5 \mathrm{~g})$ and calcined in a furnace at $550{ }^{\circ} \mathrm{C}$ (IRAM 15932). The ash was weighed, dissolved in $3 \mathrm{~mL}$ of concentrated nitric acid and diluted ( $25 \mathrm{~mL}$ final volume). The concentrations of $\mathrm{Fe}, \mathrm{Ca}, \mathrm{Cu}, \mathrm{Zn}$ and $\mathrm{Mg}$ were determined in the solutions by atomic absorption spectroscopy (direct air-acetylene flame method) (APHA 2005a), whereas $\mathrm{K}$ and $\mathrm{Na}$ were determined by atomic emission spectroscopy (flame photometry) (APHA 2005b). Calibration curves were performed with standard solutions of each metal ion (Chem-Lab) at $1000 \mathrm{mg} \mathrm{L}^{-1}$ concentration. Measurements were performed at least
Figure 1 Regions of the Province of Buenos Aires, Argentina, and the number of monofloral samples collected in each area.

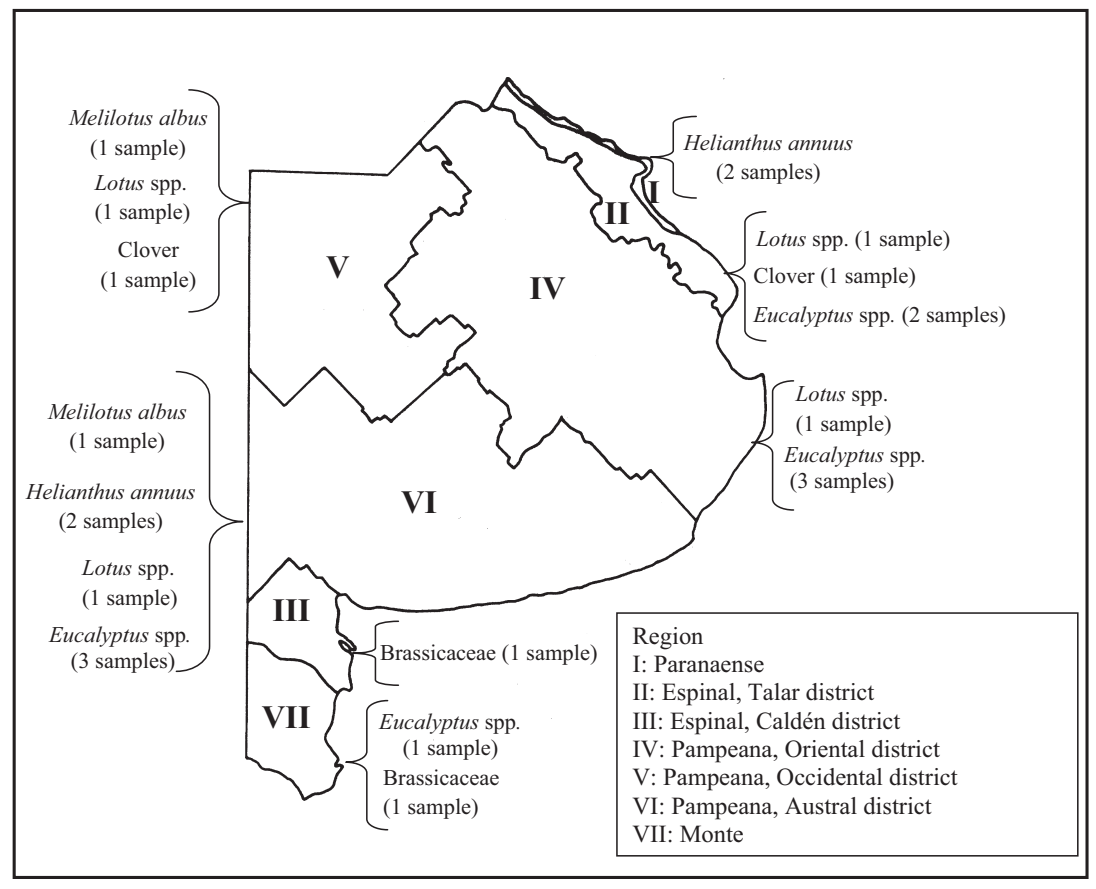


Table 1 Antioxidant activity (DPPH and FRAP), total phenolic content (TPC), colour, ash and mineral composition of honey from the different regions of the Buenos Aires province

\begin{tabular}{|c|c|c|c|c|c|c|c|c|}
\hline Region & & Paranaense I & $\begin{array}{l}\text { Talar } \\
\text { II }\end{array}$ & $\begin{array}{l}\text { Caldén } \\
\text { III }\end{array}$ & $\begin{array}{l}\text { Oriental } \\
\text { IV }\end{array}$ & $\begin{array}{l}\text { Occidental } \\
\mathrm{V}\end{array}$ & $\begin{array}{l}\text { Austral } \\
\text { VI }\end{array}$ & $\begin{array}{l}\text { Monte } \\
\text { VII }\end{array}$ \\
\hline \multirow{3}{*}{$\begin{array}{l}\text { DPPH } \\
\left(\mathrm{IC}_{50^{-1}}\right)\end{array}$} & $n$ & 5 & 5 & 6 & 5 & 7 & 7 & 5 \\
\hline & Mean & $43.5 \mathrm{bc}$ & $31.2 \mathrm{ab}$ & $21.8 \mathrm{ab}$ & $39.0 \mathrm{abc}$ & $20.1 \mathrm{a}$ & $30 a b c$ & $47.4 \mathrm{c}$ \\
\hline & SD & 11.5 & 7.6 & 25.5 & 16.2 & 10.6 & 30.0 & 10.7 \\
\hline \multirow{3}{*}{$\begin{array}{l}\text { FRAP } \\
\qquad\left(\mu \mathrm{molFe}^{+2} \mathrm{~g}^{-1}\right)\end{array}$} & $n$ & 5 & 5 & 6 & 5 & 6 & 6 & 5 \\
\hline & Mean & $2.4 \mathrm{a}$ & $2.6 \mathrm{a}$ & $1.9 \mathrm{a}$ & $2.7 \mathrm{a}$ & $1.8 \mathrm{a}$ & $1.7 \mathrm{a}$ & $3.8 \mathrm{a}$ \\
\hline & SD & 0.69 & 0.75 & 2.7 & 1.3 & 0.6 & 0.8 & 0.8 \\
\hline \multirow{3}{*}{$\begin{array}{l}\text { TPC } \\
\left(\mathrm{mg} \mathrm{kg}^{-1}\right)\end{array}$} & $n$ & 5 & 5 & 6 & 5 & 7 & 7 & 5 \\
\hline & Mean & $616 \mathrm{c}$ & $663 c$ & 428 a & $569 \mathrm{bc}$ & $449 \mathrm{ab}$ & 395 a & $693 \mathrm{c}$ \\
\hline & SD & 89.9 & 160.9 & 141.6 & 110.4 & 42.4 & 66.1 & 75.0 \\
\hline \multirow[t]{3}{*}{ Colour Pfund } & $n$ & 8 & 6 & 6 & 9 & 7 & 11 & 8 \\
\hline & Mean & $51.1 \mathrm{~b}$ & $20.6 \mathrm{a}$ & $8.2 \mathrm{a}$ & $24.8 \mathrm{a}$ & $11.2 \mathrm{a}$ & 18.49 a & $53.6 \mathrm{~b}$ \\
\hline & SD & 26.4 & 13.5 & 15.5 & 20.1 & 11.6 & 15.9 & 13.7 \\
\hline \multirow{3}{*}{$\begin{array}{l}\text { Ash } \\
\qquad\left(\mathrm{g} \mathrm{kg}^{-1}\right)\end{array}$} & $n$ & 8 & 6 & 6 & 9 & 7 & 11 & 8 \\
\hline & Mean & $1.5 \mathrm{~b}$ & $0.9 \mathrm{a}$ & $0.8 \mathrm{a}$ & $0.8 \mathrm{a}$ & $0.6 \mathrm{a}$ & $0.7 \mathrm{a}$ & $1.1 \mathrm{a}$ \\
\hline & SD & 0.5 & 0.4 & 0.4 & 06 & 0.3 & 0.4 & 0.4 \\
\hline \multirow{3}{*}{$\begin{array}{l}\mathrm{Fe} \\
\left(\mathrm{mg} \mathrm{kg}^{-1}\right)\end{array}$} & $n$ & 8 & 6 & 6 & 9 & 6 & 8 & 8 \\
\hline & Mean & $3.0 \mathrm{~b}$ & $2.7 \mathrm{ab}$ & $0.7 \mathrm{a}$ & $1.1 \mathrm{ab}$ & $1.0 \mathrm{ab}$ & $2.0 \mathrm{ab}$ & $2.4 a b$ \\
\hline & SD & 2.3 & 2.2 & 0.3 & 0.6 & 1.3 & 2.2 & 2.6 \\
\hline \multirow{3}{*}{$\begin{array}{l}\mathrm{Zn} \\
\left(\mathrm{mg} \mathrm{kg}^{-1}\right)\end{array}$} & $n$ & 8 & 6 & 6 & 9 & 6 & 8 & 8 \\
\hline & Mean & $1.6 \mathrm{~d}$ & $1.6 \mathrm{~d}$ & $1.3 \mathrm{bc}$ & $1.4 \mathrm{c}$ & $1.2 \mathrm{~b}$ & $0.9 \mathrm{a}$ & $1.3 \mathrm{bc}$ \\
\hline & SD & 0.1 & 0.1 & 0.1 & 0.2 & 0.05 & 0.1 & 0.1 \\
\hline \multirow{3}{*}{$\begin{array}{l}\mathrm{Cu} \\
\left(\mathrm{mg} \mathrm{kg}^{-1}\right)\end{array}$} & $n$ & 8 & 5 & 6 & 9 & 6 & 8 & 8 \\
\hline & Mean & $1.2 \mathrm{~d}$ & $1.1 \mathrm{~d}$ & $0.9 \mathrm{~cd}$ & $1.0 \mathrm{~cd}$ & $0.6 \mathrm{a}$ & $0.7 a b$ & $0.8 \mathrm{bc}$ \\
\hline & SD & 0.2 & 0.1 & 0.2 & 0.4 & 0.1 & 0.7 & 0.1 \\
\hline \multirow{3}{*}{$\begin{array}{l}\mathrm{Mg} \\
\left(\mathrm{mg} \mathrm{kg}^{-1}\right)^{1}\end{array}$} & $n$ & 8 & 6 & 6 & 8 & 6 & 8 & 8 \\
\hline & Mean & $1.9 \mathrm{~b}$ & $1.7 \mathrm{~b}$ & $0.5 \mathrm{a}$ & $1.8 \mathrm{~b}$ & $3.7 \mathrm{c}$ & $3.0 \mathrm{c}$ & $5.3 \mathrm{~d}$ \\
\hline & SD & 0.8 & 0.7 & 0.4 & 1.1 & 0.4 & 0.9 & 0.9 \\
\hline \multirow{3}{*}{$\begin{array}{l}\mathrm{Na} \\
\left(\mathrm{mg} \mathrm{kg}^{-1}\right)^{1}\end{array}$} & $n$ & 5 & 5 & 6 & 9 & 6 & 5 & 6 \\
\hline & Mean & $41.9 \mathrm{bc}$ & $34.8 \mathrm{ab}$ & $34.6 \mathrm{ab}$ & $46.2 \mathrm{~cd}$ & $46.6 \mathrm{~cd}$ & $26.1 \mathrm{a}$ & $55.1 \mathrm{~d}$ \\
\hline & SD & 2.1 & 15.6 & 5.9 & 9.2 & 12.6 & 2.7 & 6.3 \\
\hline \multirow{3}{*}{$\begin{array}{l}\mathrm{Ca} \\
\left(\mathrm{mg} \mathrm{kg}^{-1}\right)\end{array}$} & $n$ & 8 & 6 & 6 & 8 & 6 & 8 & 7 \\
\hline & Mean & $40.7 \mathrm{~b}$ & $38.1 \mathrm{~b}$ & $27.1 \mathrm{a}$ & $38.2 \mathrm{~b}$ & $35.2 \mathrm{~b}$ & $25.5 \mathrm{a}$ & $40.8 \mathrm{~b}$ \\
\hline & $\mathrm{SD}$ & 10.8 & 2.6 & 9.5 & 2.5 & 2.9 & 7.0 & 4.4 \\
\hline \multirow{3}{*}{$\left(\mathrm{mg} \mathrm{kg}^{-1}\right)^{1}$} & $n$ & 8 & 6 & 6 & 9 & 6 & 8 & 8 \\
\hline & Mean & $272 b c$ & $285 \mathrm{c}$ & 155 a & $268 \mathrm{bc}$ & $244 \mathrm{bc}$ & $237 \mathrm{~b}$ & $382 \mathrm{~d}$ \\
\hline & $\mathrm{SD}$ & 27.2 & 18.4 & 67.4 & 60.8 & 36.1 & 23.6 & 46.3 \\
\hline
\end{tabular}

Different letters within each row indicate significant differences among regions $(P \leq 0.05)$.

in duplicate on a Shimadzu AA-6650 spectrophotometer (Kyoto, Japan).

\section{Total phenolic content (TPC) and antioxidant capacity}

Honey aqueous solutions for antioxidant and TPC determinations were prepared by dissolving $5 \mathrm{~g}$ of honey in $5 \mathrm{~mL}$ of distilled water and sonicated for 5 min (Branson 2510, 2510e-DTH; Danbury, CT, USA) (Beretta et al., 2005).

The Folin-Ciocalteau method was used to determine the total phenolic content of honey solution, according to the method described by Escuredo et al. (2011). Absorbance was measured at $750 \mathrm{~nm}$ (Hitachi U-1900, Tokyo, Japan) using gallic acid solution $\left(250 \mu \mathrm{g} \mathrm{mL}{ }^{-1}\right)$ as standard. Results were expressed as milligrams of gallic acid $\mathrm{kg}^{-1}$.

Two different methods for antioxidant measurement were performed over the samples: DPPH radical scavenging assay (Brand-Williams et al., 1995) and FRAP assay (Benzie \& Strain, 1996). Results were expressed in terms of $\mathrm{IC}_{50}{ }^{-1}\left(\mathrm{~mL} \mathrm{~g}^{-1}\right)$ and $\mu \mathrm{mol}$ of $\mathrm{Fe}^{+2} \mathrm{~g}^{-1}$ of honey, respectively.

All determinations were performed in duplicate. All chemicals used were of analytical grade.

\section{Honey colour}

The colour of honey samples was measured using the Pfund scale. Homogeneous liquid honey, without air 
bubbles, was appropriately set in the Pfund colorimeter (Pfund Colour Grader 638 W1, Koehler Instrument Co. Inc., 168-56, Douglas Ave, Jamaica V). The colour was visually compared with standards (colour Pfund) (IRAM 15941-2). Colour grades of honey based on Pfund readings are as follows: average scale reading $\leq 8 \mathrm{~mm}$ : water-white; $8<$ reading $\leq 16$ : extra white; $16<$ reading $\leq 34$ : white; $34<$ reading $\leq 50$ : extra light-amber; $50<$ reading $\leq 85$ : light-amber; $85<$ reading $\leq 114$ : amber; reading $>114$ : dark.

\section{Statistical analysis}

Honey samples were classified according to their geographical origin. Results of DPPH, FRAP, TPC, colour, ash and the seven minerals analysed were expressed as mean values and standard deviations (SDs). To discard anomalous data, a preliminary exploratory analysis was performed using box plots, based on the median and the quartiles (Pellerano et al., 2012). Then, the statistical differences were obtained through an analysis of variance (ANOVA) followed by Fisher's test at $95 \%$ confidence level $(P \leq 0.05)$.

Results were processed using multivariate chemometric techniques involving principal component analysis (PCA) and linear discriminant analysis (LDA). Before the chemometric analysis was performed, data were normalised. The Kolmogorov test was used to confirm the normal distribution (Hernández et al., 2005; Grembecka \& Szefer, 2013).

PCA was performed to identify the most important variables related to the antioxidant activity (TPC, DPPH, FRAP, colour and ash). This chemometric technique was also performed to evaluate relationships among the different minerals analysed ( $\mathrm{Fe}, \mathrm{Zn}$, $\mathrm{Cu}, \mathrm{K}, \mathrm{Ca}, \mathrm{Mg}$ and $\mathrm{Na}$ ). PCA is a powerful tool which identifies similarities between samples and reduces the number of dimensions that describe the data by generating a new set of variables without losing much information (Granato et al., 2010). The maximal amount of variance contained in the original data set is concentrated in the first principal components.

Finally, linear discriminant analysis (LDA) was performed with the samples in which all the assays were accomplished. This methodology provides a discriminate model according to the descriptors previously defined. LDA comprises linear combinations of independent variables. These equations can be used to determine to which group each sample most likely belongs. Then, the probabilities of correct classification were estimated using validation methods (Hernández et al., 2005).

\section{Results and discussion}

\section{Mineral content}

According to Hernández et al. (2005), the mineral content of floral honey ranges from 1 to $2 \mathrm{~g} \mathrm{~kg}^{-1}$, and depends on its floral origin, climatic conditions and the extraction techniques. In this work, honey was obtained by cold extraction at the laboratory to avoid modifications during the extraction procedure. Thus, honey mineral content would only depend on the floral and/or geographical origin.

Table 1 summarises the data of the different samples, grouped by their geographical origin. In the main, Buenos Aires honey is composed by K $(76 \%$ of the mineral content), $\mathrm{Ca}$ and $\mathrm{Na}(11 \%$ and $10 \%$, respectively) and only low concentrations of $\mathrm{Cu}$ $(0.95 \%), \mathrm{Mg}(0.94 \%), \mathrm{Fe}(0.55 \%)$ and $\mathrm{Zn}(0.34 \%)$. The content of $\mathrm{K}$ and $\mathrm{Na}$ was similar to values reported by González Paramás et al. (2000), whereas the content of $\mathrm{Ca}$ and $\mathrm{Mg}$ was lower than values reported by these authors in honey from the western Spain. On the other hand, the content of $\mathrm{Na}$ and $\mathrm{K}$ was lower than values reported by Nanda et al. (2009). It must be considered that most samples analysed in the present work correspond to light honeys, which contain lower mineral levels that dark honeys (Vanhanen et al., 2011).

The heavy metal content of honey may be useful for assessing the presence of environmental contaminants, besides it could be an indicator of geographical origin (Perna et al., 2012; Alves et al., 2013). It is known from literature that trace elements such as $\mathrm{Cu}$ may be considered indicators of contamination during the honey processing (Baroni et al., 2009). Besides, $\mathrm{Zn}$ is considered a potential air or soil contaminant of anthropogenic origin. $\mathrm{Fe}$ is an important element in the classification of monofloral honeys, but the interpretation of its concentration among different regions is more difficult (Bogdanov et al., 2007). In the present work, the $\mathrm{Zn}$ and $\mathrm{Cu}$ concentrations were lower than those reported by Bogdanov et al. (2007) and can be considered lower than the toxic levels. Several authors reported similar results in blossom honeys from Palestine (Swaileh \& Abdulkhaliq, 2013), Spain (Hernández et al., 2005) and other Argentinean regions (Baroni et al., 2009; Pellerano et al., 2012).

As detailed in Table 1, significant differences were observed in the mineral content of honey from different geographical regions $(P \leq 0.05)$. The highest content of the main minerals, $\mathrm{K}, \mathrm{Na}$ and $\mathrm{Mg}$, was found in Monte (VII) region. This could be explained by the high sodium content in the soil. Besides, Occidental (V) and Oriental (IV) districts also showed considerable $\mathrm{Na}$ concentrations; this could be related to the 
catchment area of the river Salado where these regions are situated (Sánchez et al., 1998).

As previously explained, samples analysed in the present work showed low $\mathrm{Zn}$ and $\mathrm{Cu}$ content. The regions which presented slightly high values of these trace elements were Paranaense (I) and Talar (II) (Table 1). The pollution of these regions could be related to the contamination described in the Río de la Plata area (Ratto, 2010).

\section{Antioxidant activity and total phenolic content}

Antioxidant activity and total phenolic content of honey from the different regions of Buenos Aires province can be found in Table 1 .

The scavenging activity against DPPH indicates the overall hydrogen/electron donating activity of antioxidants. Honey from Monte (VII) and Paranaense (I) regions showed a higher scavenging ability than honey from Occidental $(\mathrm{V})$ region $(P \leq 0.05)$. The scavenging ability of the honeys assayed was slightly lower than the commercial honeys analysed by Beretta et al. (2005).

On the other hand, no significant differences $(P>0.05)$ were found in the antioxidant profile of honeys by the FRAP assay. This result suggests that DPPH assay would be better than FRAP assay to discriminate honey from different geographical origin.

The Folin-Ciocalteau assay was used to determinate the total phenolic content (TPC) of the samples. Honey from Monte (VII), Talar (II) and Paranaense (I) regions presented a higher phenolic content than honey from Caldén (III), Occidental (V) and Austral (VI) regions $(P \leq 0.05)$. The total phenolic content varied from 294 to $915 \mathrm{mg}$ of gallic acid $\mathrm{kg}^{-1}$ of honey and was similar to results reported by Isla et al. (2011) in honeys obtained from north-western Argentina.

\section{Ash content and colour}

Colour is an important quality parameter of honey and has considerably influence on the customer preference. Besides, several works have reported positive correlations between the honey antioxidant activity and its colour or mineral content (Sant'Ana et al., 2012; Kuś et al., 2014).

Statistical analysis showed that honey from Occidental (V) region exhibited lower colour Pfund and antioxidant values (DPPH assay) than honey from Paranaense (I) and Monte (VII) regions $(P \leq 0.05)$. As mentioned earlier, Paranaense (I) and Monte (VII) regions showed a high concentration of phenolic compounds, while Paranaense (I) region presented the highest ash content (Table 1). Furthermore, Paranaense (I) region showed the highest concentration of $\mathrm{Fe}$ (Table 1). Previous works have indicated that honey colour is possibly related to mineral content, especially to trace elements such as Fe (GonzálezMiret et al., 2005; Sant'Ana et al., 2012). Results in the present work indicate that honey colour is a combination of various factors, including TPC and mineral content.

\section{Principal component analysis (PCA)}

To provide a better understanding of the data, two different PCAs were performed. In one assay, relations among TPC, DPPH, FRAP, ash and colour were evaluated, while in the other, relations among the different minerals analysed were considered (Fig. 2).

The loading plots (which indicate the direction of each original variable) and the scores plot (which defines the position of the mean values of the original data in the new space), considering the antioxidant capacity, colour Pfund and ash content as variables, are displayed in Fig. 2a. The first two principal components explained the $93.1 \%$ of the total variance among samples. The loading plot showed that $\mathrm{CP} 1$ accounts for $80.0 \%$ of the total variance, and included most of the information concerning colour Pfund, TPC (folin) and DPPH. In contrast, ash content is mainly considered in CP 2, which explained $13.1 \%$ of the total variance.

Honey from Monte (VII), Oriental (IV) and Talar (II) regions was characterised by their antioxidant
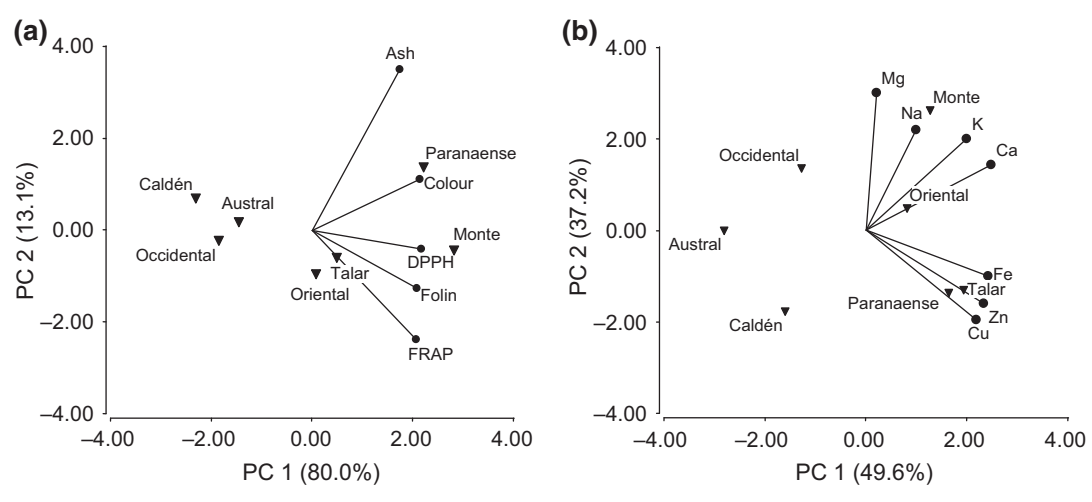

Figure 2 Principal component analysis of (a) the antioxidant markers (DPPH, FRAP), total phenolic content (Folin), colour and ash content, and (b) mineral composition, of honey from different regions of the Buenos Aires province. 
capacity, whereas honey from Paranaense (I) region was better described by its ash content and colour Pfund (Fig. 2a). These results are in agreement with data of Table 1.

Pearson's correlation coefficients were calculated to evaluate the strength of relations between the variables (Table 2a). As expected, high correlations $(P \leq 0.001)$ were found between the two antioxidant assays performed. Moreover, significant correlations were found between TPC and FRAP $(P \leq 0.001)$ and between TPC and DPPH $(P \leq 0.01)$. Some authors have indicated that trace minerals could be related to the antioxidant capacity of honeys as they can be electron donors (Sant'Ana et al., 2012; Chua et al., 2013). However, data obtained in the present work did not show any correlation between the antioxidant capacity and the trace mineral content (data not shown). From these results, it can be assumed that the antiradical activity of honeys from the Buenos Aires province would be mainly explained by the phenolic constituents. Beretta et al. (2005) reported similar conclusions when analysed the antioxidant activity of different monofloral honeys.

As can be seen in Table 2a, high correlations $(P \leq 0.001)$ were found between colour Pfund and FRAP or TPC. These results support the idea that honey colour can be related to the antioxidant capacity. Consistent with this result, Wilczyńska (2014) studied Polish honey, and had found that dark honey showed the highest antioxidant activity as well as total phenolic content. Besides, in the present work, a significant correlation was found between ash and colour $(P \leq 0.01) \quad$ (Table $2 \mathrm{a})$. These results reinforce the hypothesis that the colour of honey from the Buenos

Table 2 Correlations between (a) antioxidant activity (DPPH and FRAP), total phenolic content (TPC), ash and colour; (b) mineral content $(\mathrm{Fe}, \mathrm{Zn}, \mathrm{Cu}, \mathrm{Mg}, \mathrm{Na}, \mathrm{Ca} \text { and } \mathrm{K})^{\dagger}$

\begin{tabular}{|c|c|c|c|c|c|c|c|}
\hline (a) & \multicolumn{2}{|c|}{ DPPH } & TPC & FRAP & \multicolumn{2}{|c|}{ Colour } & Ash \\
\hline DPPH & & & & & & & \\
\hline TPC & & & 1.00 & & & & \\
\hline FRAP & & $* * *$ & $0.77^{* * *}$ & 1.00 & & & \\
\hline Colour & & & $0.70^{* * *}$ & $0.58^{* * *}$ & & & \\
\hline Ash & & & $0.49 * *$ & 0.43 & & $2 * * *$ & 1.00 \\
\hline (b) & $\mathrm{Fe}$ & $\mathrm{Zn}$ & $\mathrm{Cu}$ & $\mathbf{M g}$ & $\mathrm{Na}$ & $\mathrm{Ca}$ & K \\
\hline $\mathrm{Fe}$ & 1.00 & & & & & & \\
\hline $\mathrm{Zn}$ & $0.82 *$ & 1.00 & & & & & \\
\hline $\mathrm{Cu}$ & $0.81 *$ & $0.94 * *$ & 1.00 & & & & \\
\hline $\mathrm{Mg}$ & -0.08 & -0.42 & -0.54 & 1.00 & & & \\
\hline $\mathrm{Na}$ & -0.14 & 0.06 & -0.08 & 0.44 & 1.00 & & \\
\hline $\mathrm{Ca}$ & 0.59 & 0.54 & 0.42 & 0.43 & 0.70 & 1.00 & \\
\hline K & 0.50 & 0.23 & 0.19 & 0.70 & 0.50 & $0.86 *$ & 1.00 \\
\hline
\end{tabular}

'Significance values: $* P \leq 0.05 ; * * P \leq 0.01 ; * * * P \leq 0.001$
Aires province is determined not only by the TPC, but also by the total mineral content.

Relations among the different minerals analysed were also studied. Significant correlations were found between $\mathrm{Zn}$ and $\mathrm{Cu}$ concentrations $(P \leq 0.01)$ (Table 2b). Besides, significant correlations were found between $\mathrm{Fe}-\mathrm{Zn}$ and $\mathrm{Fe}-\mathrm{Cu}(P \leq 0.05)$. Fe can be found in honey due to its natural presence or due to anthropogenic contamination (Bogdanov et al., 2007). However, according to the present results, it could be speculated that $\mathrm{Fe}$ content in Buenos Aires honeys could be related to contamination. Similar conclusions were found by Rashed et al. (2009) who found that honeys in polluted areas presented higher concentrations of $\mathrm{Zn}, \mathrm{Cu}$ and $\mathrm{Fe}$ than honeys from unpolluted areas.

The loading plot for all the minerals considered (Fig. 2b) showed that the minerals analysed showed positive contributions to $\mathrm{PC}$, which accounted for the $49.6 \%$ of the variance. On the other hand, $\mathrm{Fe}, \mathrm{Zn}$ and $\mathrm{Cu}$ contents show negative scores of PC2, which had less contribution of the total variance $(32.7 \%)$. The score plot revealed that Talar (II) and Paranaense (I) regions were better characterised by their content of $\mathrm{Fe}, \mathrm{Zn}$ and $\mathrm{Cu}$, while Monte (VII) and Oriental (IV) regions by their content of the major minerals. This agrees with the results displayed in Table 1.

\section{Linear discriminant analysis (LDA)}

To find equations which best discriminate between honeys from the different regions analysed, a discriminant analysis was performed. In a preliminary attempt, only variables with a significant contribution to the discriminant function model were considered $(P \leq 0.05)$. However, although the ash content presented a slightly higher $P$-value $(P=0.06)$, it was also considered in the LDA to acquire a better discrimination model $(2.9 \%$ of classification error). Hence, the LDA created a model that included TPC, colour Pfund, ash content, and $\mathrm{Fe}, \mathrm{K}, \mathrm{Ca}, \mathrm{Mg}, \mathrm{Zn}$ and $\mathrm{Cu}$ concentrations.

The first dimension (CV 1) accounted for $63.7 \%$ of the data variance, separating the samples according to their $\mathrm{Zn}$ and $\mathrm{Mg}$ concentrations, TPC and colour Pfund. The second canonical variable $(21.6 \%$ of variance) separates samples according to their $\mathrm{K}$ and $\mathrm{Ca}$ concentrations. Finally, the third canonical variable only accomplishes for the $10.8 \%$ of the variance. The Wilks' Lambda value for the proposed model indicates a good discriminating power $(P<0$. 0001). The present results indicate that the best classification of honey samples could be archived considering not only by the mineral composition, but also by the TPC and colour. Similar results were found by González Paramás et al. (2000) in Spanish honeys. These authors 
Table 3 Classification matrix for the geographical origin of the honeys according to linear discriminant analysis (LDA) $(n=$ number of samples)

\begin{tabular}{|c|c|c|c|c|c|c|c|c|c|}
\hline Original Region & $n$ & Correctly classified samples (\%) & Austral VI & Caldén III & Monte VII & Occidental V & Oriental IV & Paranaense I & Talar II \\
\hline Austral & 4 & 100 & 4 & 0 & 0 & 0 & 0 & 0 & 0 \\
\hline Caldén & 5 & 80 & 0 & 4 & 0 & 0 & 0 & 0 & 1 \\
\hline Monte & 5 & 100 & 0 & 0 & 5 & 0 & 0 & 0 & 0 \\
\hline Occidental & 5 & 100 & 0 & 0 & 0 & 5 & 0 & 0 & 0 \\
\hline Oriental & 5 & 100 & 0 & 0 & 0 & 0 & 5 & 0 & 0 \\
\hline Paranaense & 5 & 100 & 0 & 0 & 0 & 0 & 0 & 5 & 0 \\
\hline Talar & 5 & 100 & 0 & 0 & 0 & 0 & 0 & 0 & 5 \\
\hline Total & 34 & 97 & 4 & 4 & 5 & 5 & 5 & 5 & 6 \\
\hline
\end{tabular}

found that the best discriminating power was found when both the physicochemical characteristics and the mineral content of honeys were considered.

The obtained LDA in this work presented excellent predictive capacity according to the misclassification table (Table 3); the original grouped cases were correctly classified with an error of $2.9 \%$.

According to the LDA, the relation among normalised variables was represented by the following equations:

$$
\begin{aligned}
\mathrm{CV} 1= & -0.86+2.08[\mathrm{Zn}]-1.65[\mathrm{Mg}]-1.33 \mathrm{TPC} \\
& -1.30 \text { colour Pfund }+1.07[\mathrm{~K}]+0.95[\mathrm{Cu}] \\
& +0.77 \mathrm{ash}-0.39[\mathrm{Fe}]-0.19[\mathrm{Ca}] \\
\mathrm{CV} 2= & 0.14+3.40[\mathrm{~K}]-1.34[\mathrm{Ca}]-1.24[\mathrm{Mg}] \\
& -1.05 \mathrm{TPC}+0.98 \mathrm{Colour} \text { Pfund }+0.68[\mathrm{Fe}] \\
+ & 0.61[\mathrm{Zn}]-0.45[\mathrm{Cu}]+0.34 \mathrm{DPPH}-0.27 \mathrm{ash} \\
\mathrm{CV} 3= & 0.08+1.65[\mathrm{~K}]-1.64[\mathrm{Mg}]+1.47[\mathrm{Zn}] \\
& -1.07 \mathrm{TPC}+0.75 \mathrm{Colour} \text { Pfund }-0.66 \text { ash } \\
& -0.3[\mathrm{Cu}]-0.02[\mathrm{Fe}]
\end{aligned}
$$

\section{Conclusion}

Honeys from the different regions of Buenos Aires province were characterised according to their antioxidant capacity and mineral composition. Although results between DPPH and FRAP showed a good correlation, DPPH seemed to be a more accurate way to characterise the antioxidant capacity of honeys.

In the present work, the antiradical activity of honeys could be explained mainly by the phenolic constituents.

Honey colour was found to be a combination of various factors, including TPC and mineral content.

Only low concentrations of $\mathrm{Zn}$ and $\mathrm{Cu}$ were detected, but a good correlation between these elements and $\mathrm{Fe}$ was found. This might suggest that the Fe content in the honeys analysed could be an indicator of contamination.
The linear discriminant analysis showed that honey samples could be correctly classified according to their TPC, colour Pfund, ash content, Fe, K, Ca, Mg, Zn and $\mathrm{Cu}$ concentrations. The honey antioxidant capacity (FRAP and DPPH) did not contribute to the discriminant function model and are not recommendable parameters to classify honeys from different regions.

\section{Acknowledgment}

This study was supported by CONICET (PIP 1643) and Universidad Nacional de La Plata, Argentina.

\section{References}

Alves, A., Ramos, A., Gonçalves, M.M., Bernardo, M. \& Mendes, B. (2013). Antioxidant activity, quality parameters and mineral content of Portuguese monofloral honeys. Journal of Food Composition and Analysis, 30, 130-138.

APHA. (2005a). Method 3111B, Standard Methods for the Examination of Water and Wastewaters, 21st edn. Washington. DC: American Public Health Association.

APHA (2005b). Method 3500-Na B. Standard Methods for the Examination of Water and Wastewaters, 21th edn. Washington, DC: American Public Health Association.

Arias, V.C., Castells, R.C., Malacalza, N., Lupano, C.E. \& Castells, C.B. (2003). Determination of oligosaccharide patterns in honey by solid-phase extraction and high-performance liquid chromatography. Chromatographia, 58, 797-801.

Baroni, M.V., Arrua, C., Nores, M.L. et al. (2009). Composition of honey from Córdoba (Argentina): assessment of North/South provenance by chemometrics. Food Chemistry, 114, 727-733.

Benzie, I.F. \& Strain, J.J. (1996). The ferric reducing ability of plasma (FRAP) as a measure of "antioxidant power": the FRAP assay. Analytical Biochemistry, 239, 70-76.

Beretta, G., Granata, P., Ferrero, M., Orioli, M. \& Facino, R.M. (2005). Standardization of antioxidant properties of honey by a combination of spectrophotometric/fluorimetric assays and chemometrics. Analytica Chimica Acta, 533, 185-191.

Blengino, C. (2013). Sector Apícola 2013 - Informe de Coyuntura No 3. Área de Estudios Sectoriales. Fuente: Dirección de Agroalimentos en base a INDEC. http://www.alimentosargentinos.gov.ar/contenido/sectores/otros/apicola/informes/2013_02Feb.pdf. (Accessed 30/03/2015).

Bogdanov, S., Haldimann, M., Luginbuhl, W. \& Gallmann, P. (2007). Minerals in honey: environmental, geographical and botanical aspects. Journal of Apicultural Research, 46, 269. 
Brand-Williams, W., Cuvelier, M.E. \& Berset, C.L.W.T. (1995). Use of a free radical method to evaluate antioxidant activity. $L W T$ Food Science and Technology, 28, 25-30.

Chua, L.S., Rahaman, N.L.A., Adnan, N.A. \& Eddie Tan, T.T. (2013). Antioxidant activity of three honey samples in relation with their biochemical components. Journal of Analytical Methods in Chemistry, Article ID 313798, 2013, 8.

Escuredo, O., Seijo, M.C. \& Fernández-González, M. (2011). Descriptive analysis of Rubus honey from the north-west of Spain. International Journal of Food Science \& Technology, 46, 2329-2336.

González Paramás, A.M., Gómez Bárez, J.A., Garcia-Villanova, R.J., Rivas Palá, T., Ardanuy Albajar, R. \& Sánchez Sánchez, J. (2000). Geographical discrimination of honeys by using mineral composition and common chemical quality parameters. Journal of the Science of Food and Agriculture, 80, 157-165.

González-Miret, M.L., Terrab, A., Hernanz, D., Fernández-Recamales, M.Á. \& Heredia, F.J. (2005). Multivariate correlation between color and mineral composition of honeys and by their botanical origin. Journal of Agricultural and Food Chemistry, 53, 2574-2580.

Granato, D., Katayama, F.C.U. \& Castro, I.A. (2010). Assessing the association between phenolic compounds and the antioxidant activity of Brazilian red wines using chemometrics. LWT-Food Science and Technology, 43, 1542-1549.

Grembecka, M. \& Szefer, P. (2013). Evaluation of honeys and bee products quality based on their mineral composition using multivariate techniques. Environmental Monitoring and Assessment, 185, $4033-4047$.

Hernández, O.M., Fraga, J.M.G., Jimenez, A.I., Jimenez, F. \& Arias, J.J. (2005). Characterization of honey from the Canary Islands: determination of the mineral content by atomic absorption spectrophotometry. Food Chemistry, 93, 449-458.

IRAM 15932 Miel. (1994) Determinación de cenizas. Instituto Argentino de Normalización .

IRAM 15941-2 Miel. (1997) Determinación de color Pfund. Instituto Argentino de Normalización.

Isla, M.I., Craig, A., Ordoñez, R. et al. (2011). Physico chemical and bioactive properties of honeys from Northwestern Argentina. LWT-Food Science and Technology, 44, 1922-1930.

Kuś, P.M., Congiu, F., Teper, D., Sroka, Z., Jerković, I. \& Tuberoso, C.I.G. (2014). Antioxidant activity, color characteristics, total phenol content and general HPLC fingerprints of six Polish unifloral honey types. LWT-Food Science and Technology, 55, 124-130.

Malacalza, N.H., Caccavari, M.A., Fagúndez, G. \& Lupano, C.E. (2005). Unifloral honeys of the province of Buenos Aires, Argentine. Journal of the Science of Food and Agriculture, 85, 1389-1396.

Malacalza, N.H., Mouteira, M.C., Baldi, B. \& Lupano, C.E. (2007). Characterisation of honey from different regions of the province of Buenos Aires, Argentina. Journal of Apicultural Research, 46, 8-14.
Nanda, V., Singh, B., Kukreja, V.K. \& Bawa, A.S. (2009). Characterisation of honey produced from different fruit plants of northern India. International Journal of Food Science \& Technology, 44, 2629-2636.

Pasquini, B., Goodarzi, M., Orlandini, S., Beretta, G., Furlanetto, S. \& Dejaegher, B. (2014). Geographical characterisation of honeys according to their mineral content and antioxidant activity using a chemometric approach. International Journal of Food Science \& Technology, 49, 1351-1359.

Pellerano, R.G., Uñates, M.A., Cantarelli, M.A., Camiña, J.M. \& Marchevsky, E.J. (2012). Analysis of trace elements in multifloral Argentine honeys and their classification according to provenance. Food Chemistry, 134, 578-582.

Perna, A., Simonetti, A., Intaglietta, I., Sofo, A. \& Gambacorta, E. (2012). Metal content of southern Italy honey of different botanical origins and its correlation with polyphenol content and antioxidant activity. International Journal of Food Science \& Technology, 47, 1909-1917.

Rashed, M.N., El-Haty, M.T.A. \& Mohamed, S.M. (2009). Bee honey as environmental indicator for pollution with heavy metals. Toxicological and Environ Chemistry, 91, 389-403.

Ratto (2010) SEA ABA. Atlas Ambiental de Buenos Aires. Contaminación del suelo URL http://www.atlasdebuenosaires.gov.ar/aaba/ index.php. [1.10.14].

Sánchez, R., Pezzola, N. \& Cepeda, J. (1998). Caracterización edafoclimática del área de influencia del INTA. EEA Hilario Ascasubi. Boletín de Divulgación, 18, 72.

Sant'Ana, L.D.O., Sousa, J.P., Salgueiro, F.B., Lorenzon, M.C.A. \& Castro, R.N. (2012). Characterization of monofloral honeys with multivariate analysis of their chemical profile and antioxidant activity. Journal of Food Science, 77, C135-C140.

Socha, R., Juszczak, L., Pietrzyk, S., Gałkowska, D., Fortuna, T. \& Witczak, T. (2011). Phenolic profile and antioxidant properties of Polish honeys. International Journal of Food Science \& Technology, 46, 528-534.

Swaileh, K.M. \& Abdulkhaliq, A. (2013). Analysis of aflatoxins, caffeine, nicotine and heavy metals in Palestinian multifloral honey from different geographic regions. Journal of the Science of Food and Agriculture, 93, 2116-2120.

Swellam, T., Miyanaga, N., Onozawa, M. et al. (2003). Antineoplastic activity of honey in an experimental bladder cancer implantation model: in vivo and in vitro studies. International Journal of Urology, 10, 213-219.

Vanhanen, L.P., Emmertz, A. \& Savage, G.P. (2011). Mineral analysis of mono-floral New Zealand honey. Food Chemistry, 128, 236240.

Wilczyńska, A. (2014). Effect of filtration on colour, antioxidant activity and total phenolics of honey. LWT-Food Science and Technology, 57, 767-774. 